Diunggah : September 2020

Diterima : Desember 2020

Dipublikasi : Desember 2020

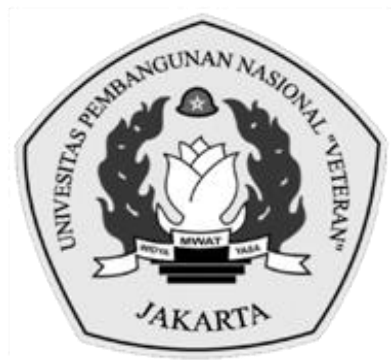

\title{
DAMPAK GOOD CORPORATE GOVERNANCE TERHADAP KINERJA PERBANKAN: MARKET RISK SEBAGAI INTERVENING
}

\author{
Sparta Sparta* \\ sparta@ibs.ac.id \\ Indonesia Banking School, Indonesia \\ *Penulis Korespondensi
}

\begin{abstract}
Abstrak
Penelitian ini bertujuan untuk membuktikan secara empiris dampak langsung mekanisme GCG terhadap kinerja perbankan di Indonesia, dampak mekanisme GCG terhadap risiko perbankan di Indonesia, dampak tidak langsung mekanisme GCG terhadap kinerja perbankan di Indonesia dengan menggunakan variabel risiko perbankan intervening. Sampel penelitian ini adalah bank konvensional yang terdaftar di Bursa Efek Indonesia dari tahun 2013 hingga 2017 dengan sampel 29 bank. Hasil penelitian menunjukkan bahwa hanya jumlah direksi dan proporsi komisaris bank independen yang berpengaruh langsung positif terhadap kinerja perbankan. Besar kecilnya komite audit perbankan berpengaruh positif terhadap total risiko dan risiko sistematis sistem perbankan. Ukuran dewan komisaris bank berpengaruh positif terhadap risiko sistematis perbankan. Jumlah direktur bank berpengaruh positif terhadap risiko sistematis dan berpengaruh negatif terhadap risiko tidak sistematis perbankan. Proporsi komisaris independen berpengaruh negatif signifikan terhadap risiko sistematis dan berpengaruh negatif terhadap unsystematic risk banking. Estimasi total risiko perbankan berpengaruh positif terhadap kinerja perbankan. Estimasi unsystematic risk banking berpengaruh negatif terhadap kinerja perbankan. Hasil penelitian ini memberikan kontribusi bagi pemegang saham yaitu untuk meningkatkan kinerja bank dengan menerapkan tata kelola perusahaan yang baik. Bagi regulator, hasil ini berkontribusi pada pemilihan calon komisaris dan komisaris independen yang lebih selektif.
\end{abstract}

Kata Kunci: Good Corporate Gavernance; Risiko Total; Risiko Tidak Sistematis; Return on Asset

\begin{abstract}
This study aims to prove empirically the direct impact of the GCG mechanism on banking performance in Indonesia, the impact of the GCG mechanism on banking risk in Indonesia, the indirect impact of GCG mechanisms on banking performance in Indonesia by using intervening banking risk variables. The sample of this research is conventional banks registered on the Indonesia Stock Exchange from 2013 to 2017 with sample 29 banks. The results of the study show that only the number of board of directors and the proportion of independent banking commissioners have a positive direct impact on banking performance. The size of the banking audit committee has a positive influence on the total risk and systematic risk of the banking system. The size of the board of commissioners of banks has a positive influence on the systematic risk of banking. The number of banking directors has a positive influence on systematic risk and has a negative influence on unsystematic risk banking. The proportion of independent commissioners has a significant negative effect on systematic risk and has a negative effect on unsystematic risk banking. The estimated total banking risk has a positive effect on banking performance. The estimation of unsystematic risk banking has a negative effect on banking performance. The results of this study have contribution for shareholders to improve the performance
\end{abstract}


of banks by implementing good corporate governance. For regulators, this result has contribution for more selective selection of candidates for commissioners and independent commissioners.

Keywords: Good Corporate Gavernance; Total Risk, Unsystematic Risk, Systematic Risk, Return on Asset

\section{PENDAHULUAN}

Data Statistik Perbankan Indonesia tahun 2017 yang dirilis oleh OJK menunjukan bahwa Kinerja perbankan sejak tahun 2013 sampai dengan 2017 mengalami kenaikan cukup baik. CAR perbankan 23,18 \% tahun 2017 dan naik dibandingkan tahun 2013. Profitabilitas tahun 2017 mengalami kenaikan dengan angka 2,45\% dibandingkan 2015 s/d 2016. Tingkat efisiensi sejak tahun 2015 mengalami peningkatan. Profit margin mengalami penurunan, Fungsi intermediary masih bertahan sekitar angka $90 \%$ an. Net income dan total aset mengalami peningkatan sejak tahun 2013 s/d akhir tahun 2017. Kredit bermasalah mengalami kenaikan sejak tahun 2014, semula 2,02\% menjadi 2,98\% tahun 2017. Berdasarkan fenomena kinerja perbankan sejak 2012 sampai dengan 2017 yang cukup membaik, namun NPL selalu naik dari tahun ketahun, sehingga ada masalah terhadap risiko perbankan. Dampak kenaikan risiko juga dapat dilihat dari sisi profitabilitas yang mengalami perlambatan pertumbuhan sejak 2012 sampai dengan 2017.

Good corporate governance (GCG) perusahaan menyatakan hubungan antar manajemen, dewan direksi, pemegang saham dan pemangku kepentingan perusahaan (Bunea, 2013 dan Ahmed, 2017). Ini mencakup peraturan dan prosedur yang harus diikuti melalui tujuan perusahaan yang telah ditetapkan. Good corporate governance perusahaan dapat meningkatkan kinerja perusahaan (Ahmed, 2017). Sejak krisis tahun 1998 sampai dengan sekarang, penerapan GCG di perbankan di Indonesia dianggap sangat penting oleh semua phak, hal ini ditandai dengan Peraturan Bank Indonesia No.8/4/PBI/2006 sebagaimana diamandemen oleh Peraturan No.8/14/2006 mengenai penerapan pada bank umum (Permatasari dan Novitasary, 2014) . PBI ini telah diganti dengan peraturan Otoritas Jasa Keuangan (POJK) No.55/OJK.03/2016, tanggal 7 Desember 2016 tentang penerapan GCG bank umum.

Salah satu penyebab terjadinya kenaikan kinerja perusahan adalah GCG perusahaan yang baik. Disamping itu, kenaikan kinerja ini juga disebabkan oleh pengelolaan risiko yang baik. Pengelolaan risiko yang baik merupakan dampak dari good corporate governance perusahaan yang baik juga (Anginer, Kunt dan Huizinga,2014). Semakin baik good corporate governance suatu perusahaan maka risiko perusahaan tersebut akan semakin rendah (Bello, 2013). Rendahnya risiko perusahaan akan menyebabkan laba bersih perusahaan akan semakin baik. Hal ini bisa berdampak pada kinerja perusahaan baik langsung ataupun tidak langsung.

Hasil penelitian sebelumnya dari beberapa Negara di dunia yang terkait dengan dampak mekanisme implementasi good corporate governance terhadap risiko perusahan menunjukan hasil signifikan negatif adalah Bello (2013), Brogi (2008), Calomiris and Mark Carlson (2016), Ibiam and Chinedu (2017), Iqbal, Strobl and Vahamaa (2015), John, Litov, and Yeung (2007), Amos Layola M, Sharon 
Sophia \& Anita M (2016), Masry, Abdelfattah and Elbahar (2016), Mcnulty, Florackis, and Ormrod (2012), Rose (2017) dan hasil studi Hassan and Mollah (2016). Hasil penelitian yang berbeda sebelumnya menunjukkan good corporate governance tidak berpengaruh terhadap pengelolaan risiko telah ditunjukkan oleh hasil studi Nzioki (2016), Roziq dan Danurwenda (2012), Hapsari (2017), Kumah, Sare and Brenard (2014). Perbedaan ini disebabkan dalam hal pengukuran variabel GCG dan manajemen risiko serta kondisi setiap negara berbeda dalam kekuatan mekanisme GCG untuk mengendalikan pengelolaan risiko yang dilakukan dalam perusahaan.

Hasil penelitian yang berbeda dari berbagai penelitian di beberapa negara menjadi alasan bagi penulis untuk mencoba melakukan riset di Indonesia mengenai dampak GCG terhadap risiko perusahaaan khususnya perbankan. Perbedaan hasil tersebut disebabkan beberapa hal. Pertama adalah perbedaan kebijakan implementasi GCG yang berbeda diberbagai negara, kedua karena adanya perbedaan dalam culture pengelolaan dari setiap negara, ketiga perbedaan waktu penelitian juga menjadi salah satu factor hasil penelitin yang berbeda hal ini karena adanya perubahan-perubahan kebijakan dan inklusi GCG bagi perusahaan di setiap negara yang membutuhkan waktu implementasi dan pemahamannya. Dan keempat adalah level risk taking yang dilakukan oleh manajemen perusahan disetiap negara juga berbeda, dan kelima industri yang berbeda juga membedakan cara pengelolaan perusahaan oleh manajemen dan cara-cara risk taking disetiap idusrti juga berbeda.

GCG secara langsung atau tidak langsung dapat memberikan dampak kepada kinerja perusahaan. Hal ini disebabkan karena pengelolaan perusahaan oleh eksekutif perusahaan dengan penerapan prinsip GCG dapat meningkatkan kinerja perusahaan melalui peningkatan laba perusahan dan nilai saham perusahaan. Riset-riset GCG banyak dilakukan di bank setelah krisis 2008, Hal ini menunjukan betapa pentingnya impelementasi GCG untuk meningkatkan kinerja dan memahami adanya masalah keagenan dalam industri perbankan (Himaj, 2014). Beberapa peneliti lain bahkan melakukan penelitian yang menggunakan variabel risiko sebagai variabel intervening dalam menjelaskan dampak GCG terhadap kinerja perusahaan. GCG dapat memiliki dampak tidak langsung terhadap kinerja perusahaan melalui risiko perusahaan sebagai variabel intevening.

Risiko perusahan dapat mempengaruhi kinerja perusahaan. Hasil penelitian dari Permatasari dan Novitasary (2014) membuktikan bahwa risk management dapat menjadi variabel intervening antara risk management dan bank performance, GCG memiliki pengaruh tidak langsung terhadap bank performance namun tidak berpengaruh langsung terhadap risk management. Hasil penelitian lain di Indonesia terkait risk management sebagai variabel intervening telah dilakukan oleh Setiawaty (2016) menunjukkan bahwa GCG mempunyai pengaruh langsung dan tidak langsung terhadap bank performance dan membuktikan bahwa risk management sebagai variabel intervening antara GCG dan bank performance. Pengaruh tidak langsung tersebut adalah pengaruh GCG terhadap bank performance melalui variable intervening risk management sedangkan pengaruh langsung adalah adanya pengaruh GCG terhadap bank performance tanpa melalui variable intervening risk mangament. 
Penelitian yang mencoba melihat dampak langsung GCG terhadap kinerja dilakukan oleh Ahmed (2017) dengan hasil terdapat pengaruh signifikan GCG terhadap kinerja perbankan syariah. Hal senada juga diperoleh dari hasil empiris Bunea (2013) pada industri perbankan di Romania dimana pasca krisis keuangan tahun 2008, implementasi GCG dapat mendorong kinerja perbankan lebih baik dari sebelumnya. Dukungan terhadap variabel GCG dapat meningkatkan kinerja perbankan juga dibuktikan dari hasil empirik penelitian yang dilakukan di beberapa Negara seperti peniltian Lai dan Choi (2014), Pan (2013), Kowalewski (2016) dan Prasojo (2015). Hal yang sama juga terjadi pada hasil penelitian di Indonesia yang menunjukkan implementasi GCG dapat berdampak pada kinerja keuangan perbankan seperti hasil penelitian Desiana, Mawardi dan Gustiana (2016) dan Purwanto (2015). Meski demikian penelitian lain menunjukkan lemahnya dampak penerapan GCG terhadap kinerja perbankan di Negara Euthopia karena lemahnya proteksi hukum terhadap pemegang saham minoritas (Fanta, Kemal and Waka, 2013). Hasil penelitian di Indonesia yang dilakukan selama periode 2010-2015 menunjukan penerapan GCG tidak dapat mendorong atau merangsang kenaikan kinerja keuangan perusahaan modal ventura yang berlokasi di 26 provinsi di Indonesia (Muhammad, Nurdin dan Haris, 2017). Namun demikian, paling tidak GCG memainkan peran penting dalam kestabilan bank, kinerja dan kemampuan untuk memberikan likuiditas dalam kondisi pasar yang sulit (Fred, 2012). Manfaat dari penerapan GCG dapat membantu mengurangi risiko dan menstimulasi kinerja perbankan lebih baik (Lai and Choi (2014).

Risiko dapat mempengaruhi secara negatif terhadap kinerja perbankan. Risiko merupakan berdampak pada turunnya aktiva bersih perusahan atau turunnya sumber daya perusahaan. Hasil penelitian sebelumnya Ekinci (2016), Hakimi dan Zagdoudi (2017), Noman et.all (2015) dan Nahar, Jubb dan Azim (2016) menunjukkan dampak negatif signifikan dari risiko terhadap kinerja bank. Sedangkan, hasil penelitian Olamide, Ulawomwa dan Ranti (2015), Mercylynne dan Omagwa (2017), menunjukkan risiko perbankan tidak signifikan berpengaruh terhadap kinerja bank. Hasil yang berbeda ini disebabkan proxy dan pengukuran risikonya berbeda.

Dari Penjelasan phenomena dan hasil empirik terkait dengan GCG, risiko perbankan dan kinerja perbankan di atas yang memberikan hasil yang berbeda, maka peniliti tertarik untuk membuktikan secara empirik pengaruh GCG terhadap risiko perbankan dan terhadap kinerja perbankan pada bank-bank go publik di Bursa Efek Indonesia (BEI) selama periode 2013 sampai dengan 2017.

Tujuan penelitian ini adalah untuk mendapatkan hasil empirik dampak mekanisme GCG di Indonesia terhadap kinerja perbankan, dampak mechanism GCG terhadap risiko perbankan dan dampak tidak langsung GCG terhadap kinerja perbankan dengan market risk sebagai variabel intervening.

Harapan dari hasil penelitian ini dapat memberikan kontribusi bagi peneliti berikutnya, bagi para praktisi, bagi Lembaga Otoritas Jasa Keuangan, dan kontribsi bagi pemegang saham. Kontribusi bagi peneliti berikutnya adalah dalam rangka pengembangan ilmu GCG terkait dengan dampaknya tehadap risk management dan kinerja keuangan perbankan. Kontribusi bagi para praktisi untuk mendapatkan data empiric mengenai dampak GCG terhadap kinerja dan risk management sebagai dasar pengambilan keputusan kebijakan GCG perusahaan dan mitigasi 
risiko. Kontribusi bagi Lembaga Otoritas Jasa Keuangan (OJK) khusunya perbankan, dapat digunakan sebagai dasar kebijakan pembuatan regulasi implementasi kegiatan GCG perbankan dan dampaknya terhadap risk management dan kinerja perbankan. Kontribusi bagi pemegang saham perbankan di Indonesia khusunya perbankan yang go publik untuk melihat sejauh mana implementasi good corporate governance perbankan dapat meningkatkan kinerja perbankan dan menurunkan risiko perbankan di Indonesia. Kontribus kedua adalah pemegang saham dapat meningkatkan jumlah direksi bank apabila peningkatan ini dapat menurunkan risiko unsystematic bank dan secara tidak langsug dapat menaikan kinerja perbankan. Kontribusi ketiga bagi pemegang saham adalah hasil penelitian ini dapat digunakan untuk melihat apakah porsi komisaris independen dapat dikragi atau dinaikan dalam rangka penurunan risiko unsystematic.

\section{TINJAUAN PUSTAKA}

\section{Pengaruh Good Corporate Governance terhadap Kinerja Perbankan}

Secara teori, riset-riset GCG yang telah dilakukan pada umumnya didominasi oleh Teori Agensi (Himaj, 2014). Hal ini karena good corporate governance perusahaan terkait dengan kepentingan pemilik terhadap perusahaan. Dalam Teori Agensi memandang perusahaan sebagai hubungan kontrak antara prinsipal (penyedia modal) dan agen (pengelola modal). Pandangan ini diungkapkan pertama kali oleh Jensen \& Meckling (1976), dimana teori agensi membahas masalah perbedaan antara tujuan dan sikap risiko pemilik perusahaan dan manager atau agen. Secara normatif hubungan principal-agent harus mencerminkan arus informasi yang efisien dan biaya menanggung risiko (Mimaj, 2014). Dalam menjelaskan praktik good corporate governance perusahaan dalam beberapa studi, peneliti lebih banyak menggunakan teori keagenan. Meskipun adanya dominasi kuat dari teori agensi dalam studi good corporate governance perusahaan, namun masih diperlukan penggunaan teori pelengkap dan alternatif lainnya untuk menafsirkan dan menjelaskan praktik good corporate governance secara global (Mimaj, 2014).

Disamping teori keagenan, teori stockholder dapat juga menjelaskan good corporate governance perusahaan. Dalam teori agensi memandang perusahaan sebagai milik pemegang saham (Alchian \& Demsetz 1972, Fama 1980, Jensen \& Meckling 1976), sedangkan ahli teori stakeholder atau pemangku kepentingan berpendapat perlu adanya kekuatan pemyeimbang dari semua pemangku kepentingan yang berkontribusi terhadap prestasi perusahaan (Cyert \& Maret 1963, Mintzberg 1983, Freeman 1984 dalam Himaj, 2014). Teori stakeholder telah membawa perhatian dan dukungan yang signifikan karena telah mengembangkan alternatif untuk good corporate governance perusahaan atau GCG yang mencakup dan menyeimbangkan banyak kepentingan.

Pengurangan biaya keagenan yang disebabkan oleh konflik kepentingan antara pemangku kepentingan institusi, maka digunakan mekanisme GCG (Sobhy, Mohamed dan Hussain, 2017). Mekanisme good corporate governance perusahaan indikatornya adalah struktur kepemilikan, komite audit, ukuran dewan komisaris, dewan direksi, proporsi komisaris independen, dan latar belakang pendidikan 
komisaris. Implementasi good corporate governance sangat tergantung dari indikator good corporate governance perusahaan tersebut. Semakin banyak jumlah komite audit maka semakin baik implementasi good corporate governance perusahaan. Semakin banyak jumlah dewan komisaris maka semakin baik implementasi good corporate governance perusaan. Semakin banyak jumlah direksi maka semakin baik implementasi good corporate governance perusahaan. Semakin banyak jumlah komisaris independen maka semakin baik implementasi good corporate governance perusahaan, begitu juga latar belakang pendidikan komisaris, semakin baik latar belakang pendidikan komisaris maka semakin baik implementasi GCG.

Kelompok penasihat OECD, melaporkan bahwa good corporate governance perusahaan yang efektif dapat meningkatkan efisiensi dan pertumbuhan ekonomi serta kepercayaan investor, sehingga dapat meningkatkan kinerja operasional dan akses ke pembiayaan eksternal (Sobhy, Mohamed dan Hussain (2017). Pernyataan OECD ini menyiratkan bahwa terdapat hubungan yang positif implementasi good corporate governance perusahaan dengan kinerja perusahaan.

Kinerja perusahaan dinilai dari sejauh mana perusahaan memperoleh hasil dibandingkan dengan sumber-sumber ekonomi yang dikorbankan untuk memperoleh hasil tersebut (Subramanyam dan Wild, 2009). Beberapa ukuran yang digunakan untuk menilai kinerja perusahaan adalah return on asset (ROA), return on equity (ROE), net profit margin (NPM), pertumbuhan aset dan pertumbuhan penjualan (Robinson et-all, 2009). Rasio-rasio ini paling banyak digunakan oleh penilti sebagai indikator kinerja perusaaan, termasuk juga perbankan. Dalam penelitian ini indikator yang digunakan untuk mengukur kinerja perbankan adalah ROA, karena ROA lebih mencerminkan kemampuan perusahaan dalam memberikan imbal hasil kepada penyandang dana perusahaan.

Penelitian yang telah menguji dampak langsung GCG terhadap kinerja dilakukan oleh Ahmed (2017) yang menunjukkan adanya pengaruh signifikan GCG dengan menggunakan indek terhadap kinerja perbankan syariah. Hal senada juga dinyatakan dari hasil empirik Bunea (2013) pada industri perbankan di Romania dimana pasca krisis keuangan tahun 2008, implementasi GCG dapat mendorong kinerja perbankan lebih baik dari sebelumnya. Hasil yang sama juga dibuktikan dari hasil empirik penelitian yang dilakukan di beberapa Negara seperti peniltian Lai dan Choi (2014), Pan (2013), Kowalewski (2016) dan Prasojo (2015). Penelitian di Indonesia yang menunjukkan dampak implementasi GCG terhadap kinerja keuangan perbankan diantaranya hasil penelitian Desiana, Mawardi dan Gustiana (2016) dan Purwanto (2015). Hasil yang berbeda ditemukan pada hasil penelitian Wardoyo-Agustini (2015) yang menyatakan bahwa indikator mekanisme good corporate governance perusahaan tidak berdampak pada kinerja perbankan.

\section{$\mathrm{Ha}_{1}$ : GCG berpengaruh langsung positif terhadap kinerja perbankan.}

\section{Pengaruh Good Corporate Governance terhadap Risiko Perbankan}

Risiko perbankan dapat diukur dari pendekatan kegiatan fundamental perbankan atau dari pendekatan pasar industri perbankan (Sparta, 2018). Risiko perbankan yang diukur dari kegiatan fundamental bank seperti risiko kredit dengan menggunakan rasio non performing loan rasio (NPL), risiko likuiditas 
menggunakan rasio Loan to deposit ratio ( $L D R$ ), risiko solvency menggunakan capital adequacy ratio (CAR), dan risiko off balance sheet menggunakan rasio proporsi off balance terhadap total aktiva bank, dan lain sebagainya (Hull, 2012). Pada umumnya risiko fundamental menggunakan ukuran data akuntansi laporan keuangan.

Ukuran risiko perbankan dengan pendekatan pasar adalah risiko sistematik/risiko pasar, risiko unsysistematic, total risiko, risiko suku bunga dan risiko valas (Sparta, 2018). Pengukuran risiko pendekatan pasar dilakukan dengan menggunakan data-data di pasar uang dan pasar modal (Karim and Chan, 2007). Dalam penelitian ini, risiko bank diukur dengan menggunakan pendekatan pasar adalah risiko systematic, risiko unsystematic dan total risiko.

Sebagian besar Eksekutif perusahaan lebih menghindari risiko daripada pemilik perusahaan. Hal ini disebabkan karena manager perusahan tidak menginginkan perusahaan tempat ia bekerja menjadi bangkrut sehingga ia akan kehilangan pekerjaan (Anginer, Kunt dan Huizinga, 2014). Manager akan berusaha sebaik mungkin untuk mengelola perusahaan dengan baik agar risiko perusahaan menjadi turun dan nilai perusahaan meningkat.

Banyak hasil penelitian membuktikan bahwa tingkat good corporate governance yang tinggi akan menaikan pengungkapan informasi keuangan perusahaan (Bello, 2013), meningkatkan kualitas pelaporan dan memberikan kontribusi penurunan informasi asimetris antara manajer dan penyandang dana perusahaan atau investor (Bello, 2013). Penyebab lain dari pengurangan informasi asimetris adalah peningkatan kegiatan monitoring oleh pemegang saham atau pihak-pihak yang berkepentingan. Peningkatan monitoring akan menurunkan tindakan high risk taking oleh manajemen, sehingga potensi risiko dimasa mendatang semakin berkurang.

Hasil penelitian sebelumnya dari beberapa Negara di dunia terkait dengan dampak mekanisme good corporate governance terhadap risiko sebagian besar membuktikan bahwa semakin kuat good corporate governance perusahaan maka semakin kecil risiko perusahaan. Hasil penelitian yang sesuai dengan hal tersebut adalah penelitian Bello (2013), Brogi (2008), Calomiris and Mark Carlson (2016), Ibiam and Chinedu (2017), Iqbal, Strobl and Vahamaa (2015), John, Litov, and Yeung (2007), Amos, Layola M, Sharon Sophia \& Anita M (2016), Masry, Abdelfattah and Elbahar (2016), Mcnulty, Florackis, and Ormrod (2012), Rose (2017), Hassan dan Mollah (2016), dan hasil studi dari Mathew, Ibrahim dan Archbold (2018). Hasil penelitian lain berbeda ditunjukkan dari hasil studi Nzioki (2016), Roziq dan Danurwenda (2012), Hapsari (2017), dan Kumah, Sare and Brenard (2014).

\section{$\mathrm{Ha}_{2}$ : GCG berpengaruh negatif terhadap risiko perbankan.}

\section{Pengaruh Risiko terhadap Kinerja Perbankan}

Berdasarkan pandangan teori keuangan pendekatan pasar (lihat buku-buku manajemen keuangan), menyatakan bahwa high risk high return (Mercylynne, Mumbi Wanjugu dan Job Omagwa (2017). Return disini terkait dengan return pasar, namun dari aspek fundamental, kaitan risiko dengan kinerja keuangan adalah sebaliknya yaitu high risk low income namun kalo risko yang dihadapi lebih 
kecil dari hasil yang diperoleh bank, maka high risk high return dapat berlaku (Sounders, 2011),

Risiko yang tinggi akan berimplikasi kepada peningkatan kerugian atau penuruan income suatu perusahaan. Hal ini sesuai dengan definisi risiko yang menyatakan bahwa ketidaksesuaian realisasi dengan ekpektasi yang berdampak kepada penurunan sumber daya yang dimiliki oleh perusahaan (Sounders, 2011). Hasil penelitian Nahar, Jubb dan Azim (2016) membuktikan bahwa risiko sebagai variabel penentu terhadap kinerja perbankan. Ekinci (2016), Hakimi dan Zagdoudi (2017), dan Noman et.all (2015) menunjukkan dampak negatif signifikan dari risiko terhadap kinerja bank. Sedangkan, hasil penelitian Olamide, Ulawomwa dan Ranti (2015), Mercylynne dan Omagwa (2017), menunjukkan hasil pengaruh tidak signifikan risiko perbankan terhadap kinerja bank. Hasil berbeda disebabkan proxy dan metode pengukuran risiko yang berbeda. Namun secara umum kebanyakan hasil penelitian sebelumnya menunjukkan hasil pengaruh signifikan positf risiko terhadap kinerja bank.

\section{$\mathrm{Ha}_{3}$ : estimasi risiko perbankan berpengaruh positif terhadap kinerja perbankan atau GCG berpengaruh tidak langsung positif terhadap kinerja perbankan.}

\section{METODOLOGI PENELITIAN}

Populasi penelitian adalah industri perbankan, dengan sampel bank umum go publik di Bursa Efek Indonesia, jumlah sampel bank yang digunakan adalah 29 bank dengan jangka waktu penelitian adalah lima tahun (2013-2017) sehingga jumlah observasinya adalah 145 obeservasi. Kriteria sampel adalah 1), Bank umum listing di Bursa Efek Indonesia (BEI) selama periode penelitian 2013 sampai dengan 2017. Alasan memilih periode ini adalah selama periode ini tidak ada kejadian ekonomi dan peristiwa politik yang cukup mempengaruh struktur data sampel penelitian di perbankan go publik, 2). Bank yang sahamnya aktif diperdagangkan di BEI. Jenis data digunakan adalah data panel, dengan waktu lima tahun (2013-2017) dan observasi bank go publik di BEI dan memenuhi kriteria pemilihan sampel penelitian di atas. Sumber data dari laporan keuangan bank audited di situs www.ojk.go.id dan data harga pasar saham bank IHSG di BEI dalam harian. Tabel 1 menunjukkan ringkasan definisi variabel penelitian.

Tabel 1. Definisi Variabel Penelitian

\begin{tabular}{|c|c|c|c|c|}
\hline No & $\begin{array}{c}\text { Simbol } \\
\text { Variabel }\end{array}$ & Definisi & Formulasi & $\begin{array}{c}\text { Skala } \\
\text { pengukuran }\end{array}$ \\
\hline 1 & $R_{i t}$ & $\begin{array}{l}\text { Return saham perusahaan i } \\
\text { pada waktu t. }\end{array}$ & $\begin{array}{l}=\frac{\left[P_{t-1}-P_{t 0}\right]}{P_{t-1}} \mathrm{x} \\
100 \%\end{array}$ & Rasio \\
\hline \multirow{3}{*}{2} & BANKRISK $K_{i t}:$ & & & Rasio \\
\hline & $\begin{array}{l}\text { a. Total Risk } \\
\text { Bank (TRISK) }\end{array}$ & $\begin{array}{l}\text { Standard deviasi dari return } \\
\text { saham }\end{array}$ & $=\sigma_{i t}$ of $R_{i t}$ & \\
\hline & $\begin{array}{r}\text { b. Market risk } \\
\text { (systematic }\end{array}$ & $\begin{array}{l}\text { Risiko pasar adalah terkait } \\
\text { dengan indikator ekonomi. }\end{array}$ & $\beta_{1 \text { of it }}$ of $R_{m}$ & Rasio \\
\hline
\end{tabular}




\begin{tabular}{|c|c|c|c|c|}
\hline \multirow[t]{3}{*}{ No } & $\begin{array}{c}\text { Simbol } \\
\text { Variabel }\end{array}$ & Definisi & Formulasi & $\begin{array}{c}\text { Skala } \\
\text { pengukuran }\end{array}$ \\
\hline & $\begin{array}{l}\text { risk) } \\
\text { (SYRISK) }\end{array}$ & $\begin{array}{l}\text { Koefisien beta return pasar } \\
\text { terhadap return saham } \\
\text { individu }\end{array}$ & & \\
\hline & $\begin{array}{l}\text { c. Unsystemati } \\
\text { c risk } \\
\text { (USYRISK) }\end{array}$ & $\begin{array}{l}\text { Adalah risiko terkait dengan } \\
\text { fundamental perusahaan. } \\
\text { Diperoleh dari standard } \\
\text { deviasi dari error term } \\
\text { model pasar }\end{array}$ & $=\sigma_{i t}$ of $\in_{i t}$ & Rasio \\
\hline 3 & $G C G_{i t}$ & $\begin{array}{l}\text { Good corporate governance } \\
\text { perusahaan khususnya } \\
\text { perbankan dilihat dari sisi } \\
\text { mekanisme penerapan GCG } \\
\text { yaitu; } \\
\text { 1. komite audit (KAUDT), } \\
\text { 2. ukuran dewan komisaris } \\
\quad \text { (UDKOM), } \\
\text { 3. dewan direksi (UDDIR), } \\
\text { 4. proporsi komisaris } \\
\text { independen (PKOMI) }\end{array}$ & $\begin{array}{l}\text { 1. jumlah } \\
\text { anggota } \\
\text { komite audit, } \\
\text { 2. ukuran dewan } \\
\text { komisaris, } \\
\text { 3. jumlah } \\
\text { anggota } \\
\text { dewan direksi, } \\
\text { 4. proporsi } \\
\text { komisaris } \\
\text { independen }\end{array}$ & Rasio \\
\hline 4 & $\begin{array}{l}\text { Kinerja bank } \\
\text { (return on } \\
\text { asset=ROA) }\end{array}$ & $\begin{array}{l}\text { Imbal hasil yang dapat } \\
\text { diberikan industri } \\
\text { perbankan kepada seluruh } \\
\text { penyandang di perbankan } \\
\text { tersebut }\end{array}$ & $\begin{array}{l}\text { ROA=net income } \\
\text { / total asset }\end{array}$ & rasio \\
\hline 5 & $L T A_{i t}$ & $\begin{array}{l}\text { natural logaritma total aset } \\
\text { pada bank I tahun } t \text {, }\end{array}$ & $\begin{array}{l}=\text { Ln of total } \\
\text { Asset }\end{array}$ & Rasio \\
\hline
\end{tabular}

Sumber: Data Diolah (2020)

Terdapat empat persamaan penelitian utama. Rumus 1 digunakan untuk mengukur total risk, sistematik risk, dan risiko unsystematic risk. Risiko unsystematic risk diukur dari standar deviasi dari return saham bank i (Choudry, 1980).

$$
\begin{array}{r}
\text { Rumus 1. Perhitungan Risiko } \\
R_{i t}=\beta_{o}+\beta_{1} R_{m, t}+\in_{i t} \ldots \ldots \ldots \ldots \ldots \ldots \ldots \ldots \ldots \ldots \ldots \ldots \ldots \ldots \ldots \ldots
\end{array}
$$

Dimana $R_{i t}$ adalah return saham pada bank i pada tahun $\mathrm{t}, R_{m, t}$ adalah Indek Harga Saham Gabungan di Bursa Efek Indonesia pada tahun t. $\epsilon_{i t}$ adalah error term pada Rumus 1 pada bank i tahun t. Sementara, Rumus 2 digunakan untuk melihat dampak GCG terhadap kinerja perbankan.

Rumus 2. Dampak GCG terhadap Kinerja Perbankan

$$
R O A_{i t}=\partial_{0}+\partial_{1} G C G_{i t}+\partial_{2} L T A_{i t}+\varepsilon_{i t}
$$

Dimana $R O A_{i t}$ adalah return on asset ada bank t pada tahun t, $G C G_{i t}$ adalah GCG pada bank i pada tahun $\mathrm{t}, L T A_{i t}$ adalah long term asset pada bank i pada tahun $\mathrm{t}, \varepsilon_{i t}$ adalah error term Rumus 2 pada bank i tahun $\mathrm{t}$. Berdasarkan Tabel 1, GCG 
terdiri dari empat variabel yaitu KUDT adalah jumlah anggota komite audit, UDKOM adalah ukuran dewan komisaris, UDDIR adalah jumlah anggota dewan direksi, dan PKOMI adalah proporsi komisaris independen. Sehubungan dengan hal ini maka secara otomatis Rumus 2 menjadi Rumus 2.1 .

Rumus 2.1. Dampak GCG Dikembangkan terhadap Kinerja Perbankan $R O A_{i t}=\partial_{0}+\partial_{1} \mathrm{KUDT}_{i t}+\partial_{2} \mathrm{UDKOM}_{i t}+\partial_{3} \mathrm{PKOMI}_{i t}+\partial_{4} L T A_{i t}+\varepsilon_{i t}$

Persamaan ketiga penelitian digunakan untuk melihat dampak mekanisme GCG terhadap risiko perbankan. Risiko perbankan yang digunakan adalah tiga jenis yaitu total banking risk, systematic risk, dan unsystematic risk,

$$
\begin{gathered}
\text { Rumus 3. Risiko Bank } \\
\text { BANKRISK }_{i t}=\emptyset_{0}+\emptyset_{1} \mathrm{KUDT}_{i t}+\emptyset_{2} \mathrm{UDKOM}_{i t}+\emptyset_{2} \mathrm{PKOMI}_{i t}+\omega_{i t}
\end{gathered}
$$

Dimana BANKRISK $K_{i t}$ adalah salah satu dari tiga jenis risiko bank i tahun $\mathrm{t}$ yang digunakan, dan $G C G_{i t}$ adalah mekanisme good corporate governance bank i tahun $t, \omega_{i t}$ adalah error term persamaan 3 pada bank i tahun $t$. Berdasarkan Tabel 1, variabel independen BANKRISK dalam penelitian ini terdiri dari tiga jenis risiko yaitu TRISK adalah total risiko, SYRISK adalah systemic risk, dan USYRISK adalah unsystimic risk. Hal ini menyebabkan Rumus 3 diturunkan menjadi Rumus 3.1, 3.2, dan 3.3.

$$
\begin{aligned}
& \text { Rumus 3.1. Risiko Total } \\
& \text { TRISK }_{i t}=\emptyset_{0}+\emptyset_{1} \mathrm{KUDT}_{i t}+\emptyset_{2} \mathrm{UDKOM}_{i t}+\emptyset_{2} \mathrm{PKOMI}_{i t}++\omega_{i t} \\
& \text { Rumus 3.2. Risiko Sistematik } \\
& S Y R I S K_{i t}=\emptyset_{0}+\emptyset_{1} \mathrm{KUDT}_{i t}+\emptyset_{2} \mathrm{UDKOM}_{i t}+\emptyset_{2} \mathrm{PKOMI}_{i t}++\omega_{i t} \\
& \text { Rumus 3.3. Risiko Tidak Sistematik } \\
& U_{S Y R I S K}=\emptyset_{0}+\emptyset_{1} \mathrm{KUDT}_{i t}+\emptyset_{2} \mathrm{UDKOM}_{i t}+\emptyset_{2} \mathrm{PKOMI}_{i t}++\omega_{i t}
\end{aligned}
$$

Rumus 4 digunakan untuk melihat dampak risiko perbankan terhadap kinerja perbankan.

Rumus 4. Risiko Perbankan terhadap Kinerja Perbankan

$$
R O A_{i t}=\gamma_{0}+\gamma_{1} B A \widehat{N K R I S K} K_{i t}+\gamma_{2} L T A_{i t}+e_{i t}
$$

Dimana $R O A_{i t}$ adalah return on asset ada bank t pada tahun t, BATKRISK $K_{i t}$ adalah salah satu dari tiga jenis risiko bank yang digunakan pada bank I, tahun $t$, dimana ukuran variabel ini diambilkan dari estimasi risiko yang diperleh dari persamaan penelitian kedua di atas. Sesuai dengan penjelasan sebelumnya bahwa variabel $B A \widehat{N K R} I S K_{i t}$ teridiri dari tiga variabel yaitu $\widehat{T R I S K} K_{i t}$, USYRISK $K_{i t}$, dan $S \widehat{Y R I S} K_{i t}$. Dengan demikian Rumus 4 ditunkan menjadi Rumus 4.1.

Rumus 4. Risiko-Risiko Perbankan terhadap Kinerja Perbankan $R O A_{i t}=\gamma_{0}+\gamma_{1} T \widehat{R I S K}_{i t}+\gamma_{2} S Y R I S K_{i t}+\gamma_{3} U_{S Y R I S K_{i t}}+\gamma_{4} L T A_{i t}+e_{i t}$ 
$L T A_{i t}$ adalah long term asset pada bank i pada tahun t, dan $e_{i t}$ adalah error term persamaan 4.1 pada bank i tahun $\mathrm{t}$.

Uji-uji yang digunakan agar persamaan regresi yang dihasilkan fit maka dilakukan uji Cow untuk menguji apakah model yang fit menggunakan fixed effect model atau common effect model dan uji Housman untuk menguji apakah persamaan yang fit menggunakan fixed effect model atau random effect model. Sedangkan untuk menguji gejala klasik dilakukan uji normalitas residual dari persamaan regresi, uji multikolineariti, uji otokorelasi dan untuk menghindari gejala heteroskedasitas pada persamaan penilitian maka digunakan white cross section standard error and covariance. Penggunaan white cross section standard error and covariance dapat menghindari gejala heteroskedastisitas pada lima persamaan regresi yang akan dihasilkan (Woodrige, 2005).

\section{HASIL DAN PEMBAHASAN}

Deskriptif statistik dari sampel penelitian dapat dilihat pada tabel 2. Pada table 2 terlihat bahwa nilai mean, median, standard deviasi, maximumnilai, minimum nilai, skewness, kurtosis, sum square deviasi dan jumlah observasi dan jumlah cross section untuk masing-masing vaiabel peneltian yang digunakan dalam penelitian ini.

Tabel 2. Deskriptif Statistik

\begin{tabular}{|c|c|c|c|c|c|c|c|c|c|c|c|}
\hline & TA & NI & ROA & KAUDT & UDKOM & UDDIR & PKOMI & LTA & TRISK & SYRISK & UNSYRISK \\
\hline Mean & $1.63 \mathrm{E}+14$ & $5.69 \mathrm{E}+12$ & 0.0051 & 3.7931 & 5.2552 & 7.2897 & 0.5693 & 31.3577 & 2.3346 & 0.4765 & 2.1484 \\
\hline Median & $6.82 \mathrm{E}+13$ & $7.27 \mathrm{E}+11$ & 0.0109 & 3.0000 & 5.0000 & 7.0000 & 0.5000 & 31.8538 & 2.0806 & 0.3278 & 1.9616 \\
\hline Maximum & $1.13 \mathrm{E}+15$ & $1.40 \mathrm{E}+14$ & 0.0987 & 8.0000 & 9.0000 & 12.000 & 0.8000 & 34.6577 & 6.9773 & 5.8508 & 6.8607 \\
\hline Minimum & $7.58 \mathrm{E}+09$ & $-1.14 \mathrm{E}+13$ & -0.8958 & 2.0000 & 2.0000 & 3.0000 & 0.3333 & 22.7489 & 0.5073 & -2.7171 & 0.6083 \\
\hline Std. Dev. & $2.55 \mathrm{E}+14$ & $1.74 \mathrm{E}+13$ & 0.0788 & 1.2904 & 1.8135 & 2.4379 & 0.0919 & 2.23878 & 1.2357 & 0.9040 & 1.0943 \\
\hline Skewness & 2.2335 & 5.3065 & -10.367 & 1.1484 & 0.2408 & 0.1023 & 0.4554 & -1.6575 & 1.9819 & 1.1597 & 2.3706 \\
\hline Kurtosis & 7.2460 & 35.4299 & 119.3205 & 4.3807 & 1.8796 & 1.9071 & 2.4878 & 7.7408 & 7.5197 & 11.472 & 9.9922 \\
\hline Jarque-Bera & 229.4823 & 7034.5410 & 84343.9500 & 43.3879 & 8.9850 & 7.4692 & 6.5981 & 202.1843 & 218.3387 & 466.1775 & 431.1881 \\
\hline Probability & 0.0000 & 0.0000 & 0.0000 & 0.0000 & 0.0112 & 0.0239 & 0.0369 & 0.0000 & 0.0000 & 0.0000 & 0.0000 \\
\hline Sum & $2.36 \mathrm{E}+16$ & $8.25 \mathrm{E}+14$ & 0.7348 & 550.0000 & 762.0000 & 1057.0000 & 82.5473 & 4546.8660 & 338.5152 & 69.0954 & 311.5166 \\
\hline Sum Sq. Dev. & $9.36 \mathrm{E}+30$ & $4.34 \mathrm{E}+28$ & 0.8949 & 239.7931 & 473.5586 & 855.8345 & 1.2168 & 721.7486 & 219.8890 & 117.6864 & 172.4236 \\
\hline Obser & 145 & 145 & 145 & 145 & 145 & 145 & 145 & 145 & 145 & 145 & 145 \\
\hline Cross sections & 29 & 29 & 29 & 29 & 29 & 29 & 29 & 29 & 29 & 29 & 29 \\
\hline
\end{tabular}

Sumber: Data Diolah (2020)

\section{Uji Normalitas dan Gejala Klasik}

Hasil uji normalitas residual hasil regresi Rumus 2, Rumus 3 (terdiri dari Rumus 3.1, 3.2 dan 3.3) dan Rumus 4 dengan menggunakan Jarque-Bera dapat dilihat pada Tabel 5. Hasilnya menunjukan distribusi normal residuanya adalah normal. 
Tabel 3. Uji Normalitas Residual Regresi Persamaan 2, 3 dan 4

\begin{tabular}{lrrr} 
Residual & Mean & $\begin{array}{c}\text { Jarque-Bera } \\
\text { Stat }\end{array}$ & Probabilitas \\
\hline RESID2.1 & 0.0001 & 4.2162 & 0.1215 \\
RESID3.1 & 0.0099 & 1.7955 & 0.4075 \\
RESID3.2 & $<-0.0001$ & 3.8521 & 0.1457 \\
RESID3.3 & $<-0.0001$ & 1.4383 & 0.4872 \\
RESID4.1 & 0.0008 & 0.3442 & 0.8419 \\
\hline
\end{tabular}

Sumber: Data Diolah (2020)

Tabel 4 menunjukkan korelasi antar variabel independen menunjukkan tingkat korelasi dibawah 0,8, sehingga tidak terdapat gejala multikolinearitras dari persamaan regresi penelitian ini. Tidak terdapatnya gejala muticollenearity tersebut, maka masing-masing independen tidak berkorelasi kuat sehingga variable tersebut bisa digunakan sebagai independen variabel dalam satu persamaan regresi dan disamping itu untuk memenuhi salah satu syarat $B L U E$ dari persamaan hasil regresi yang dihasilkan sehingga persamaan regresi tersebut bisa dgunakan sebagai alat analisis untuk menguji hipotesis penelitian.

Tabel 4. Multikoliearitas

\begin{tabular}{|c|c|c|c|c|c|c|c|c|c|}
\hline & TA & NI & ROA & KAUDT & UDKOM & UDDIR & PKOMI & LTA & TRISK SYRISK \\
\hline NI & 0.2658 & & & & & & & & \\
\hline ROA & -0.0967 & 0.8701 & & & & & & & \\
\hline KAUDT & 0.5308 & 0.1054 & 0.0746 & & & & & & \\
\hline UDKOM & 0.5826 & 0.0829 & 0.1725 & 0.4441 & & & & & \\
\hline UDDIR & 0.6627 & 0.0806 & 0.1958 & 0.3724 & 0.7104 & & & & \\
\hline PKOMI & -0.1757 & 0.0280 & 0.0722 & -0.0827 & -0.5332 & -0.3398 & & & \\
\hline LTA & 0.6401 & 0.1164 & 0.0932 & 0.4256 & 0.5838 & 0.7125 & -0.1186 & & \\
\hline TRISK & -0.1181 & -0.1429 & -0.0393 & -0.1788 & -0.1920 & -0.2539 & 0.0816 & -0.1203 & \\
\hline SYRISK & 0.2471 & 0.1153 & 0.0921 & 0.1948 & 0.0816 & 0.1854 & 0.0027 & 0.1985 & -0.0720 \\
\hline UNSYRISK & -0.3617 & -0.1303 & -0.0439 & -0.2712 & -0.2781 & -0.3514 & 0.1514 & -0.2225 & $0.7523-0.0433$ \\
\hline
\end{tabular}

Sumber: Data Diolah (2020) 
Tabel 5 menunjukkan hasil regresi data panel dari penelitian ini.

Tabel 5. Hasil Regresi Data Panel

\begin{tabular}{|c|c|c|c|c|c|}
\hline \multirow{2}{*}{$\begin{array}{c}\text { Variabel } \\
\text { (Coff, } \\
\text { SE, } \\
\text { t-stat) } \\
\end{array}$} & \multirow{2}{*}{$\begin{array}{c}\text { Persamaan } \\
2.1 \\
\\
\text { ROA }\end{array}$} & \multicolumn{3}{|c|}{ Persamaan 3} & \multirow{2}{*}{$\begin{array}{c}\text { Persamaan } \\
4.1 \\
\\
\text { ROA } \\
\end{array}$} \\
\hline & & $\begin{array}{c}3.1 \\
\text { TRISK }\end{array}$ & $\begin{array}{c}3.2 . \\
\text { SYSRIK }\end{array}$ & $\begin{array}{c}3.3 . \\
\text { UNSYRISK }\end{array}$ & \\
\hline \multirow{3}{*}{$\mathrm{C}$} & 0.1298 & 1.8183 & 0.2082 & 1.5540 & -0.1665 \\
\hline & 0.1027 & 0.5406 & 0.2804 & 0.4673 & 0.0812 \\
\hline & 1.2646 & 3.3637 & 0.7423 & 3.3255 & -2.0489 \\
\hline \multirow{3}{*}{ KUDT } & 0.0048 & 0.1060 & 0.3594 & -0.0088 & \\
\hline & 0.0030 & 0.0267 & 0.0702 & 0.0451 & \\
\hline & 1.5782 & $3.9775^{* * *}$ & $5.1184 * * *$ & -0.1942 & \\
\hline \multirow{3}{*}{ UDKOM } & 0.0013 & 0.0084 & -0.2205 & -0.0484 & \\
\hline & 0.0026 & 0.0085 & 0.0553 & 0.0469 & \\
\hline & 0.5007 & 0.9930 & $-3.9890^{* * *}$ & -1.0325 & \\
\hline \multirow{3}{*}{ UDDIR } & 0.0022 & -0.0431 & 0.0560 & -0.0580 & \\
\hline & 0.0013 & 0.0526 & 0.0248 & 0.0133 & \\
\hline & $1.6779^{*}$ & -0.8184 & $2.2546^{* *}$ & $-4.3500^{* * *}$ & \\
\hline \multirow{3}{*}{ PKOMI } & 0.0294 & 0.6743 & -0.6041 & 2.2922 & \\
\hline & 0.0158 & 0.7892 & 0.3000 & 0.6347 & \\
\hline & $1.8602^{*}$ & 0.8544 & $-2.0138^{* *}$ & $3.6113^{* * *}$ & \\
\hline \multirow{3}{*}{ ETRISK } & & & & & 0.0410 \\
\hline & & & & & 0.0238 \\
\hline & & & & & $1.7252^{*}$ \\
\hline \multirow{3}{*}{ ESYRISK } & & & & & 0.0032 \\
\hline & & & & & 0.0033 \\
\hline & & & & & 0.9637 \\
\hline \multirow{3}{*}{ EUNSYRISK } & & & & & -0.0089 \\
\hline & & & & & 0.0020 \\
\hline & & & & & $-4.3852^{* * *}$ \\
\hline \multirow{3}{*}{ LTA } & -0.0058 & & & & 0.0030 \\
\hline & 0.0029 & & & & 0.0011 \\
\hline & $-2.0380^{* *}$ & & & & $2.7720^{* * *}$ \\
\hline R square & 0.7641 & 0.6409 & 0.6806 & 0.6860 & 0.6116 \\
\hline Adjusted R square & 0.6940 & 0.5383 & 0.5894 & 0.5963 & 0.5006 \\
\hline F-statistic & 10.896 & 6.2472 & 7.4595 & 7.6477 & 5.5116 \\
\hline Prob(F-statistic) & 0.0000 & 0.0000 & 0.0000 & 0.0000 & 0.0000 \\
\hline Durbin-Watson stat & 2.1535 & 2.2852 & 2.1294 & 2.2157 & 1.9329 \\
\hline \multicolumn{6}{|c|}{$\begin{array}{l}\text { Keterangan; } \\
* \text { *) }=\operatorname{Sign} \propto 10 \%, * *)=\operatorname{Sign} \propto 5 \% ; * * *)=\operatorname{Sign} \propto 1 \%\end{array}$} \\
\hline
\end{tabular}

Sumber: Data Diolah (2020)

\section{Analisis Pengaruh GCG terhadap Kinerja Perbankan}

Hasil empirik penelitian ini menujukan jumlah direksi bank dan proporsi komisaris independen yang berpengaruh positif secara langsung terhadap kinerja perbankan. Semakin banyak jumlah direksi bank maka akan menaikkan kinerja bank. Hal ini akan mengefektifkan kordinasi dan pengawasan dari operasional bank sehingga akan meningkatkan kinerja perbankan. Begitu juga dengan semakin 
banyaknya jumlah dewan komisaris independen maka semakin meningkatkan kinerja perbankan. Hasil ini sesuai dengan hasil penelitian Ahmed (2017), Burnea (2013), Lai and Choi (2014), Pan (2013), Kowalewski (2016), Prasojo (2015), Roziq dan Danurwenda (2012), Purwanto (20150, dan Srairi (2015). Hasil ini berbeda seperti yang dilakukan oleh Wardoyo (2015).

Jumlah komite audit dan jumlah komisaris tidak dapat secara langsung meningkatkan kinerja perbankan. Pemegang saham harus hati-hati dalam memutuskan menambah jumlah dewan komisaris bank dan jumlah komite audit. Apabila akan ditambah jumlahnya maka perlu pertimbangan professional dan bukan politik. Lebih jauh, apabila dikaitkan dengan agency theory hasil ini membuktikan bahwa komisaris sebagai perwakilan dari pemegang saham harus mampu memonitor kinerja direksi. Jumlah komisaris tidak dapat menjamin hal tersebut.

\section{Analisis Pengaruh GCG terhadap Risiko Perbankan.}

Implementasi good corporate governance perusahaan di perbankan tidak memberikan dampak negatif terhadap total risiko perbankan. Hasil empirik penelitian ini menunjukan kondisi anomali yang terjadi pada jumlah komite audit. Kenaikan jumlah komite audit dapat menaikan risiko perbankan. Fenomena ini menunjukan bahwa kenaikan jumlah komite audit tidak mampu menurunkan risiko perbankan, justru akan menaikan risiko perbankan secara signifikan. Apabila ingin menurunkan risikonya justru harus menurunkan jumlah komite audit. Ini bisa mengidentifkasikan bahwa apabila komite audit adalah orang-orang yang professional maka peningkatan jumlah nya akan menganggu kepentingan dewan direksi sehingga dewan direksi tidak konsentrasi bekerja (Aebi, vincent, Gabriele Sabato dan Markus Schmid (2012) yang membawa dampak pada kenaikan risiko perbankan, atau sebaliknya kenaikan risiko perbankan dapat memicu kenaikan kinerja perbankan (Ekinci, 2016), Dengan banyaknya jumlah komite audit, maka dewan direksi akan dihadapkan untuk terus melakukan tindakan taking risk sehingga ini akan meningkatkan sumber pendapatan bagi bank (Mercylynne, Mumbi Wanjugu dan Job Omagwa, 2017),. Lebih jauh, sebagian besar produk perbankan memiliki karakteristik high risk high return, dimana semakin berisiko produk perbankan tersebut maka semakin tinggi return yang dihasilkan produk tersebut. Hasil penelitian ini tidak sesuai dengan hasil penelitian sebelumnya yang dilakukan oleh Bello (2013), Brogi (2008), Calomiris and Mark Carlson (2016), Ibiam and Chinedu (2017), Iqbal, Strobl and Vahamaa (2015), John, Litov and Yeang (2007), Amos Layola M, Sharon Sophia \& Anita M (2016), Masry, Abdelfattah and Elbahar (2016), menulty, Florackis and Ormrod (2012), Rose (2017), Hasan dan Mollah (2016) dan hasil studi dari Mathew, Ibrahim dan Archblod (2018). Ketidaksesuaian ini disebabkan karena objek sampel dan tempat penelitannya yang berbeda, alat ukur variabel yang digunakan juga berbeda serta regulasi setiap negara yang berbeda dalam iplementasi GCG dan penanganan risiko yang terjadi. Hasil penelitian sesuai dengan hasil penelitian yang dilakukan oleh Nzioki (2016), Roziq dan Danurwenda (2012), Hapsari (2017), Kumah, Sare dan Brenard (2014).

Meskipun implementasi good corporate governance perusahan di perbankan tidak mampu menurunkan total risiko perbankan, namun dua 
komponen implementasi good corporate governance perusahaan dapat menurunkan risiko sistematik perbankan yaitu jumlah anggota komisaris dan proporsi komisaris independen. Semakin banyak jumlah anggota komisaris dan semakin banyak porsi komisaris independen maka akan menurunkan risiko sistematik perbankan. Meningkatnya jumlah anggota komisaris akan meningkatkan monitoring dan tekanan dari komsaris terhadap direksi untuk tidak melakukan kegiatan risk taking sehingga risiko perbankan dapat diturunkan diperbankan tersebut. Hasil ini sesuai dengan beberapa penelitian sebelumnya seperti hasil penenlitian Bello (2013), Brogi (2008), Calomiris and Mark Carlson (2016), Ibiam and Chinedu (2017), Iqbal, Strobl and Vahamaa (2015), John, Litov and Yeang (2007), Amos, Layola M, Sharon Sophia \& Anita M (2016), Masry, Abdelfattah and Elbahar (2016), menulty, Florackis and Ormrod (2012), Rose (2017), Hasan dan Mollah (2016) dan hasil studi dari Mathew, Ibrahim dan Archblod (2018). Dan tidak sesuai dengan hasil penelitian Nzioki (2016), roziq dan Danurwenda (2012), Hapsari (2017), Kumah, Sare dan Brenard (2014).

Dua komponen mekanisme implementasi good corporate governance perusahan di perbankan yaitu jumlah komite audit tidak mampu menurunkan risiko sistematik perbankan, justru signifikan berpengaruh positif terhadap kenaikan risiko sistematik perbankan. Peran komite audit untuk mengurangi risiko perbankan, tidak mampu meningkatkan monitoring terhadap kegiatan direksi berkaitan dengan risk taking sehingga risiko sistematik perbankan semakin meningkat. Lebih jauh, dari implementasi good corporate governance yang berkaitan dengan jumlah komisaris perbankan menujukkan bahwa implementasi jumlah komisaris juga tidak mampu menurunkan risiko sistematik perbankan. Hal ini diduga karena penunjukan komisaris sebagian besar banyak didasarkan factor politik dan leamhnya melihat faktr kompetensi sehingga komisaris yang tidak kompeten tidak mampu mengawasi taking risk yang dilakukan oleh manajemen perbankan. Dengan demikian dua komponen imlementasi Good Corporate Governance perusahaan yaitu jumlah komite audit dan jumlah komisaris tidak mampu menurunkan risiko sistematik perbankan sehingga hasil ini tidak sesuai dengan hasil penelitian Bello (2013), Brogi (2008), Calomiris and Mark Carlson (2016), Ibiam and Chinedu (2017), Iqbal, Strobl and Vahamaa (2015), John, Litov and Yeang (2007), Amos Layola M, Sharon Sophia \& Anita M (2016), Masry, Abdelfattah and Elbahar (2016), menulty, Florackis and Ormrod (2012), Rose (2017), Hasan dan Mollah (2016) dan hasil studi dari Mathew, Ibrahim dan Archblod (2018). Dan hasil ini sesuai dengan hasil penelitian Nzioki (2016), Roziq dan Danurwenda (2012), Hapsari (2017), Kumah, Sare dan Brenard (2014).

Jumlah direksi tidak berdampak pada penurunan total risk perbankan dan juga risiko sistematik risk perbankan, namun jumlah direksi perbankan dapat menurunkan risiko unsystematic risk perbankan. Ini artinya bahwa Direksi perbankan mampu menurunkan risiko perbankan yang ditimbulkan dari aspek makro diluar fundamental bank. Aspek makro tersebut seperti direksi perbankan dapat mengantisipasi kenaikan dan penurunan tingkat inflasi, tingat kredit macet industry perbankan, pertumbuhan GDP dan bahkan dapat mengantiispasi perubahan IHSG di Bursa Efek Indonesia dan di negara lainnya dan serta perubahan kurs di pasar uang. Hal ini tentu saja dapat dipahami bahwa banyak bank-bak devisa sangat aktif melakukan trading financial asset nya di pasar uang, 
pasar berjangka sehingga para manajer bank lebih sensitive terhadap perubahan indikator makro ekonomi. Semakin banyak jumlah direksi perbankan maka semakin baik implemtasi good corporate governance perusahaan sehingga direksi mampu menurunkan risiko unsystematic risk. Hasil ini sesuai dengan hasil penelitian Bello (2013), Brogi (2008), Calomiris and Mark Carlson (2016), Ibiam and Chinedu (2017), Iqbal, Strobl and Vahamaa (2015), John, Litov and Yeang (2007), Amos Layola M, Sharon Sophia \& Anita M (2016), Masry, Abdelfattah and Elbahar (2016), menulty, Florackis and Ormrod (2012), Rose (2017), Hasan dan Mollah (2016) dan hasil studi dari Mathew, Ibrahim dan Archblod (2018). Dan hasil ini tidak sesuai dengan hasil penelitian Nzioki (2016), roziq dan Danurwenda (2012), Hapsari (2017), Kumah, Sare dan Brenard (2014).

Komponen lain good corporate governance yaitu jumlah komite audit, jumlah komisaris dan proporsi komisaris independen tidak mampu menurunkan risiko unsystematic risk perbankan. Namun hal sebaliknya terjadi, hasil penelitian ini menunjukan bahwa komponen proporsi komisaris independen dapat meningkatkan secara signifikan risiko unsystematic risk. Hasil ini tidak sesuai dengan hasil penelitian Bello (2013), Brogi (2008), Calomiris and Mark Carlson (2016), Ibiam and Chinedu (2017), Iqbal, Strobl and Vahamaa (2015), John, Litov and Yeang (2007), Amos, Layola M, Sharon Sophia \& Anita M (2016), Masry, Abdelfattah and Elbahar (2016), menulty, Florackis and Ormrod (2012), Rose (2017), Hasan dan Mollah (2016) dan hasil studi dari Mathew, Ibrahim dan Archblod (2018). Hasil berbeda dengan hasil penelitian sebelumnya karena diduga proses rekruitmen komisaris independen di Indonesia lebih banyak nuansa politisnya dibadingkan dengan nuansa komptensi calon komisaris independen itu sendiri dibandingkan dengan negara luar Indonesa dan juga kmpetensi komisari independen di nagera luar tersebut lehib memahami indikator makro ekonomi terkait usystemati risk. Dan hasil ini sesuai dengan hasil penelitian Nzioki (2016), Roziq dan Danurwenda (2012), Hapsari (2017), Kumah, Sare dan Brenard (2014).

\section{Analisis Pengaruh Intervening Risiko Terhadap Kinerja Perbankan}

Risiko yang dipengaruhi oleh implementasi good corporate governance perusahaan dapat mempengaruhi secara signifikan negatif terhadap kenerja perbankan. Dalam penelitian ini, ketiga jenis risiko menunjukkan bahwa hanya unsystematic risk yang mempengaruhi signifikan negatif terhadap kinerja perbankan, dengan demikian dapat dikatakan bahawa pengaruh GCG terhadap kinerja perbankan dipengaruhi oleh risiko unsystematic perbankan. Hasil ini sesuai dengan penelitian Nahar, Jubb dan Azim (2016), Ekinci (2016), Hakimi dan Zagdoudi (2017), dan Norman et.all (2015). Dan hasil ini tidak konsisten dengan hasil penelitian Olamide, Ulawomwa dan Ranti (2015), serta Mercylynne dan Omagwa (2017) yang menemukan bahwa risiko perbankan tidak signifikan mempengaruhi kinerja perbankan.

Total risk dengan mempertimbangkan implementasi GCG mempengaruhi signikan positif terhadap kinerja perbankan. Implementasi good corporate governance perusahaan khusunya jumlah komite audit memiliki pengaruh terhadap total risiko perbankan. Total resiko perbankan mempunyai pengaruh positif terhadap kinerja perbankan. Semakin berisiko bank, maka semakin membaik kinerja bank. Hal ini tidak sesuai dengan teori risk management yang 
menyatakan bahwa risiko mempunyai pengaruh negatif terhadap kinerja perbankan (Sounders, 2011). Sedangkan dari sisi pandangan teori keuangan (lihat buku-buku manajemen keuangan), menyatakan bahwa high risk high return. Teori keuangan menjelaskan kaitan risiko dengan return yang mengambarkan kinerja perusahaan dari sudut pasar. Hasil penelitian ini selaras dengan teori keuangan bahwa semakin tinggi risiko perbankan maka peluang untuk mendapatkan profit semakin tinggi. Bank beroparasi dengan menghadang banyak risiko sehingga ada potensi keuntungan dibalik risiko yang diambil oleh perbankan tersebut. Hasil penelitian tidak sesuai dengan hasil penelitian sebelumnya yng menyatakan bahwa risiko memiliki dampak negatif terhadap kinerja keuangan seperti hasil penelitian Nahar, Jubb dan Azim (2016), Ekinci (2016), Hakimi dan Zagdoudi (2017), dan Norman et.all (2015).

\section{SIMPULAN}

Kesimpulan penilitian adalah dampak langsung komponen implementasi good corporate governance bank terhadap kinerja bank tanpa mempertimbangkan risiko yaitu jumlah direksi dan porsi komisaris independen berdampak positif signifikan terhadap kinerja perbankan, sedangkan komponen lain tidak berdampak. Kemudian dampak komponen implementasi good corporate governance bank terhadap risiko perbankan yaitu pertama, jumlah komite audit berdampak positif signifikan terhadap total risiko dan systematic risk, namun tidak berdampak terhadap unsystematic risk. Lebih jauh jumlah komisaris berdampak negatif signifikan terhadap systematic risk perbankan, namun tidak berdampak pada total risk dan unsystematic risk perbankan. Berikutnya, jumlah direksi perbankan berdampak positif terhadap systematic risk dan berdampak negatif terhadap unsytematic risk perbankan, sedangkan terhadap total risk tidak berdampak. Porsi komisaris independen berdampak negatif terhadap systematic risk dan berdampak positif terhadap unsystematic risk namun tidak berdampak terhadap total risk. Estimasi total risk berdampak positif terhadap kinerja perbankan, estimasi unsystematic risk berdampak negatif terhadap kinerja perbankan, dan systematic risk tidak berdampak terhadap kinerja perbankan. Jumlah komite audit berdampak tidak langsung positif terhadap kinerja perbankan, jumlah direksi berdampak tidak langsung positif terhadap kinerja perbankan dan porsi komisaris independen berdampak tidak langsung negatif erhadap kinerja perbankan, dan semakin besar ukuran bank maka semakin meningkat kinerja perbankan tersebut begitu sebaliknya.

Penilitian ini mempunyai keterbatasan dan saran yaitu hasil penelitian ini hanya bisa di implementasikan untuk industri perbankan yang go publik, sehingga sarannya apabilia ingin digunakan hasil penelitian ini untuk indusri lain maka perlu dilakukan penelitian pada industry tersebut. Keterbatasan dan saran yang kedua, Hasil penelitian memiliki keterbatasan dalam mengantisipasi dampak dari leverage dan utilisasi aset. Saran dari peneliti untuk keterbatasan penelitian ini bagi akademisi untuk melakukan penelitian yang juga membahas dampak leverage dan utilisasi asset terhadap risk dan kinerja keuanan. Berikutnya keterbatsaan dan sarannya adalah hasil penelitian perbankan ini menggunakan metode analisis data 
dengan regresi data panel saran kami sebaiknay juga mempertibangkan untuk menngunakan SEM.

Hasil penelitian ini memberikan kontribusi kepada pemegang saham perbankan di Indonesia khusunya perbankan yang go publik bahwa implementasi good corporate governance perbankan belum sepenuhnya meningkatkan kinerja perbankan dan menurunkan risiko perbankan di Indonesia. Dampak penerapan GCG di perbankan terhadap kinerja sangat tergantung pada risiko perbankan tersebut. Dampak implementasi GCG terhadap perbankan sangat tergantung pada total risiko perbankan dan risiko sistematik perbankan. Beberapan implikasi bagi pemegang ssaham terhadao hasil penelitian ini adalah pertama. pemegang saham dapat meningkatkan jumlah komite audit karena dapat menaikan total risiko perbankan, total risiko perbankan memiliki dampak positif terhadap kinerja perbankan. Dengan demikian kenaikan komite audit secara tidak langsung dapat meningkatkan kinerja perbankan.

Kedua, pemegang saham dapat meningkatkan jumlah direksi bank karena peningkatan ini akan menurunkan risiko unsystematic bank. Penurunan risiko unsistematik bank akan menaikan kinerja perbankan. Sehingga meningkatkan jumlah direksi bank secara tidak langsung dapat menaikan kinerja perbankan.

Dan ketiga, pemegang saham dapat melakukan pengurangan porsi komisaris independen karena pengurangan ini akan menyebabkan risiko unsystematik akan mengalami penurunan. Penurunan risiko unsystematic akan menaikan kinerja perbankan. Sehingga secara tidak langsung, pengurangan porsi komisaris independen akan menaikan kinerja perbankan.

Hasil penelitian ini dapat juga memberikan implikasi bagi regulator terkait dengan kebijakan implementasi good corporate governance perbankan. Implikasi pertama adalah, regulator dapat mengatur kebijakan yang mengarah untuk bankbank besar dapat menambah jumlah komite audit, meningkatkan jumlah direksi banknya, dan ketiga dapat mengurangi porsi komisaris independen di perbankan tersebuit. Hal ini karena komisaris independen tidak begitu banyak perannya dalam meningkatkan kinerja perbankan secara tidak langsung apabila risiko perbankan dipertimbangkan.

Bagi manajemen bank, hasil penelitian ini memberikan implikasi untuk menyetujui dalam rapat RUPS bila pemegang saham ingin melakukan penambahan direksi, penambahan anggota komite audit dan pengurangan porsi komisaris independe karena hal ini akan meningkatkan kinerja bank khususnya bank besar. Karena semakin besar bank, maka kinerja perbankan semakin baik.

\section{DAFTAR PUSTAKA}

Aebi, vincent, Gabriele Sabato dan Markus Schmid (2012), "Risk management, corporate governance, and bank performancein the financial crisis" Journal of Banking \& Finance, 36 (2012) 3213-3226

Amos, Layola M, Sharon Sophia \& Anita M (2016), Effect of Corporate Governance on Loan Loss Provision in Indian Public Banks, Amity Journal of Corporate Governance 1(1), (1-15) 
Anginer, Deniz, Asli Demirgur-Kunt, Hany Huizinga and Kebin MA, (2014), "Corporate Governance and Bank Insolvency Risk: International Evidence1, JEL Clasification G21.M21.

Ahmed, Elsiddig Ibrahim (2017)," The Impact of Corporate Governance on Islamic Banking Performance: The Case of UAE Islamic Banks", Journal of Banking \& Finance" Vol.2017.issue 09, September.

Aktan, Bora, Sok-Gee Chan, Sasa Zikovic, and Pinar Evrim Mandaci (2013), "Off balance sheet activities impact on commercial bank's performance: an emerging market perspective", economska Istrazivanja-economic research, (ISSN 133-677xprint), vol 26(3): p.117-132.

Alchian, A. A. dan Demsetz, H. (1972). "Production, Information Cost, and Economic Organization." American Economic Review, 62, 777-795.

Bello, Ahmad (2013), "Corporate Governance and Risk Exposure of Banksin Nigeria" British Journal of Arts and Social Sciences, ISSN: 2046-9578, Vol.12 No. I (2013)

Brogi, Marina (2008), Regulation corporate governace and risk management in banks and insurance companies", melalui http://citeseerx.ist.psu.edu/viewdoc/download?doi=10.1.1.537.7242\&rep=r ep1\&type=pdf

Bunea, (2013), "The corporate governance impact on banking performance increase", Cross-Cultural Management Journal, Volume XV, Issue 2 (4) / 2013

Calomiris, Charles W. and Mark Carlson (2016), "Corporate governance and risk management at unprotected bank National Banks in the 1890s. JEL classification: G21, G32, N21, melalui https://www0.gsb.columbia.edu/faculty/ccalomiris/papers/Corporate\%20G overnance $\% 20$ and $\% 20$ Risk $\% 20$ Management $\% 20$ at $\% 20$ Unprotected $\% 20 \mathrm{Ba}$ nks.pdf

Chaudry, Mukesin (1980), "Commercial Bank's Off-balance sheet activities and Their relation with market-based", $4^{\text {th }}$ afir international colloquim. P.1241 1276.

Desiana, Lidia, Mawardi dan Selly Gustiana (2016), "Pengaruh good corporate governace terhadap profitabilitas (ROE) pada Bank Umum Syariah di Indonesia periode 2010-2015", I-Finance Vol. 2. No. 2. Desember 2016

Ekinci (2016), "The Effect of Credit and Market Risk on Bank Performance: Evidence from Turkey" International Journal of Economics and Financial Issues, 2016, 6(2), 427-434.

Fama, E. (1980). "Agency Problems and the Theory of the Firm". Journal of Political Economy, Vol. 88, 288-307.

Fanta, Asbenafi Beyene, Kelifa Srmolo Kemal and Yodit Kassa Waka, (2013), "Corporate governance and impact on bank performance" melalui http://article.sciencepublishinggroup.com/pdf/10.11648.j.jfa.20130101.12.p $\underline{\mathrm{df}}$

Fred, Otieno Miseda (2012), "The effect of corporate governance on financial performance of commercial banks in Kenya" melalui http://erepository.uonbi.ac.ke/bitstream/handle/11295/14833/Otieno The \%20 effect $\% 20$ of $\% 20$ corporate $\% 20$ governance $\% 20$ on $\% 20$ financial $\% 20$ perf 
ormance $\% 20$ of $\% 20$ Commercial $\% 20$ Banks $\% 20 \mathrm{in} \% 20$ Kenya.pdf?sequence $=3$ \&isAllowed $=\mathrm{y}$

Hapsari (2017), "Pengaruh good corporate governance perusahaan terhadap manajemen risiko pada perbankan indonesia', Jurnal Muara Ilmu Ekonomi dan Bisnis, Vol. 1, No. 2, Oktober 2017: hlm 1-10

Hakimi dan Zagdoudi (2017), "Liquidity risk and bank performance: an empirical test for Tunisian banks", Business and Economic Research ISSN 2162-4860 2017, Vol. 7, No. 1

Hassan and Mollah (2016). "Corporate governance risk-taking and firm performance of Islamic banks during global financial crisis", JEL Clasification Code: G34, Y90, G01, melalui: https://www.isfin.net/sites/isfin.com/files/corporate_governance_risktaking_and_firm_performance_of_islamic_banks_during_global_financial_crisis -.pdf

Himaj, Shkendtje (2014), "Corporate governance in banks and its impact on risk and performance: review of literature on the selected governance mechanism", Journal of Central Banking Theory and Practice, 2014, 3, pp. 5385.

Hull, John C. 2012, Risk management and financial institution, third edition, USA: Willey Finance

Ibiam and Chinedu (2017), "Effect of Corporate Governance on Risk Management of Commercial Banks in Nigeria", International Journal of Finance and Accounting, 2017, 6(5): 145-153.

Iqbal, Jamshed, Shasa Strobl and Sami Vahamaa (2015), “Corporate governance and the systemic risk of financial institution", JEL classification: G01, G20, G21, G30, G32, G34,

Jensen, M.C. and Meckling, W.H. (1976). "Theory of the firm: managerial behaviour, agency costs, and ownership structure". Journal of Financial Economics 3, 305-360.

John, Kose, Lubomir Litov, and Bernard Yeung (2007), “Corporate Governance and Risk Taking", Jounal of finance, juni 2007.

Kowalewski, Oskar (2016) "Corporate governance and corporate performance: financial crisis (2008)", Management Research Review, Vol. 39 Issue: 11, pp.1494-1515, melalui https://doi.org/10.1108/MRR-12-2014-0287.

Lai Ping-fu and On-na CHOI (2014), "Corporate Governance and Financial Performance of Bank in Asian Regions and Recommendations" Asian Journal of Finance \& Accounting, ISSN 1946-052X, 2014, Vol. 6, No. 2

Masry, Ahmed A. El, Tarek Abdelfattah and Ehab Elbahar (2016), 'Corporate Governance and risk management in GCC Banks" Corporate Ownership and Control Journal / Volume 13, Issue 3, 2016

Mathew, Sudha, Ibrahim dan Archbold (2018) "Corporate governance and firm risk", Corporate Governance: The International Journal of Business in Society, Vol. 18 Issue: 1, pp.52-67, melalui: https://doi.org/10.1108/CG-02-2017$\underline{0024}$

Mcnulty, Terry, Chris Florackis, and Philip Ormrod (2012), Corporate governance and risk: a study of board structure and process, London: The Association of Chartere Certificate Accountants, ISBN: 978-1-85908-480-9 
Mercylynne, Mumbi Wanjugu dan Job Omagwa (2017), “Credit Risk Management And Financial Performance Of Selected Commercial Banks In Kenya" IOSR Journal of Business and Management (IOSR-JBM) e-ISSN: 2278-487X, p-ISSN: 2319-7668. Volume 19, Issue 11. Ver. VII (November. 2017), PP 92-98.

Musalli, Mahfoudh Abdul Karem dan ku Nur Izah Ku Ismail (2012), Corporate governance, bank specific characteristic, banking industry characteristics, and intellectual capital (IC), performance oh banks in Arab Gulf corporation council (GCC) countries", Asian Aacademy of Management Journal of Accounting and Finance (AAMJAF), Vol. 8 (Supp. 1), 115-135, 2012

Nahar, Shamsun, Chistine Jubb dan Muhammad I Azim (2016), "Risk governance and performance: a developing country perspective", Managerial Auditing Journal, Vol. 31 Issue: 3, pp.250-268, melalui https://doi.org/10.1108/MAJ02-2015-1158,

Noman, abu Hanifa Md, Sajeda perwin, Mustafa Manir Chodhury (2015)," The Effect of Credit Risk on the Banking Profitability: A Case on Bangladesh", Global Journal of Management and Business Research: C Finance, Volume 15 Issue 3 Version 1.0 Year 2015, Type: Double Blind Peer Reviewed International Research Journal, Publisher: Global Journals Inc. (USA), Online ISSN: 2249-4588 \& Print ISSN: 0975-5853

Nzioki, Ndumai Cornelius (2016), "Effect of corporate governance on credit risk management in commercial banks in Kenya', Tesis, master of business administration, School of Business, University of Nairobi, melalui http://erepository.uonbi.ac.ke/bitstream/handle/11295/99016/EFFECT\%2 0OF\%20CORPORATE\%20GOVERNANCE\%200N\%20CREDIT\%20RISK\%20M ANAGEMENT\%20IN\%20COMMERCIAL\%20BANKS\%20IN\%20KENYA\%20C N.pdf?sequence $=1 \&$ isAllowed $=\mathrm{y}$

(https://keuangan.kontan.co.id/news/ojk-kinerja-perbankan-januari-2018-masihstabil

Olamide, Olusanmi, Uwuigbe Ulawomwa dan Uwuigbe Olubukunola Ranti (2015), "The Effect of Risk Management on Bank's Financial Performance in Nigeria", Journal of Accounting and Auditing: Research \& Practice, , Vol. 2015 (2015), $\begin{array}{llll}\text { Article ID } & \text { 239854, } & 7 & \text { pages }\end{array}$ http://www.ibimapublishing.com/journals/JAARP/jaarp.html DOI: $10.5171 / 2015.239854$

Permatasari, Ika dan Retno Novitasary, (2014), "Pengaruh Implementasi Good Corporate Governance terhadap Permodalan dan Kinerja Perbankan di Indonesia: Manajemen Risiko Sebagai Variabel Intervening" Jurnal Ekonomi kuantitaif Terapan, Vol 7 No.1, Februari 2014, p.52-59.

Prasojo (2015), "Pengaruh Penerapan Good Corporate Governance terhadap Kinerja Keuangan Bank Syariah" Jurnal Dinamika Akuntansi dan Bisnis, Vol. 2, No. 1, Maret 2015, p. 59-69.

Purwanto, Wawan (2015). "Analysis of the Impact of Good Corporate Governance and Bank Fundamentals to the Financial Performance of Banking Institutions in the Indonesian Stock Exchange (BEI)" , Research Journal of Finance and Accounting, Vol.6, No.8, 2015, p.1 s/d 6. 
Robinson, Thomas R, Hennie Van Greening, Elaine Henry, and Michael A. Broihahn (2009). International financial statement analysis, Investment Series-CFA Institute, New Jersey: John Wiley \& Son.

Roziq, Ahmad dan Herdian Nisar Danurwenda (2012), "Pengaruh good corporate governance terhadap corporate social responsibility melalui risiko bisnis dan kinerja keuangan pada bank umum syariah di Indonesia", Jurnal Akuntansi, Universitas Jember, p90-109.

Rose, Caspar (2017), "The Relationship between Corporate Governance Characteristics and Credit Exposure in Banks: Implications for Financial Regulation" European Journal of Law and Economics, Vol. 43, No. 1, 02.2017, p. 167-194.

Roziq dan Danurwenda (2012), "Pengaruh good corporate governance terhadap corporate social responsibility melalui risiko bisnis dan kinerja keuangan pada bank umum syariah di Indonesia”, Jurnal Akuntansi, Universitas Jember, melalui: https://jurnal.unej.ac.id/index.php/JAUJ/article/download/.../1010

Setiawaty (2016), "Pengaruh Mekanisme Good Corporate Governance terhadap Kinerja Perbankan dengan Manajemen Risiko sebagai Variabel Intervening": Jurnal Ekonomi dan Manajemen, Volume 13, (1), 2016 ISSN print: 1907-3011, ISSN online: 2528-1127 http://journal.febunmul.net

Sobhy, Amina E., Ehab K.A. Mohamed dan Mosing M. Hussain (2017), “Corporate Governance and bank performance: Experience with Ten Asian Countries”, melalui http://ssrn.com/abstract=2900333.

Sounders, Anthony (2011), Financial Institutions Management - a risk management approach, Seventh Edition, Singapore: Mc.Graw-Hill.

Sparta, (2018), "Dampak kegiatan off balance sheet terhadap risiko perbankan di Indonesia", laporan penelitian hibah internal Indonesia Banking School, P3M - IBS.

Srairi, Samir (2015), “Corporate Governance Disclosure Practices and Performance of Islamic Banks in GCC Countries" Journal of Islamic Finance, Vol. 4 No. 2 (2015) $001-017$.

Subramanyam, KR and John J. Wild., (2009), Financial statement analysis, Tenth edition, Singapore: McGraw-Hill

Wardoyo dan Agustini (2015), "Dampak implementasi RGEC terhadap nilai perusahaan yang go public di Bursa efek Indonesia", Journal Ilmiah: KINERJA, Volume 19, No.2, Th. 2015: Hal. 126-138. 